\title{
Interim Report by Asia International Grid Connection Study Group
}

\author{
Ryo Omatsu ${ }^{1, *}$ \\ ${ }^{1}$ Renewable Energy Institute, Senior Researcher, 1-13-1 Nishi-Shimbashi,Minato-ku,Tokyo,Japan
}

\begin{abstract}
The Asia International Grid Connection Study Group Interim Report examines the feasibility of developing an international grid connection in Japan. The Group has investigated different cases of grid connections in Europe and conducted research on electricity markets in Northeast Asia, and identifies the barriers and challenges for developing an international grid network including Japan. This presentation introduces basic contents of the interim report by the Study Group.
\end{abstract}

\section{Introduction}

The Asia International Grid Connection Study Group has been established in 2016 for the purpose of conducting research on international electric power networks and recommending what to do in order to open up its possibilities in Asia.

The Research Group is composed mainly of researchers of electric power systems and energy policy, experts in renewables, and people from related businesses. Since its founding in July 2016, with Renewable Energy Institute (REI) designated as secretariat, the Research Group has been discussing potentials of an international power network in Asia in a straightforward manner from multiple viewpoints. Study Group also visited Europe in January and February 2017 to inspect transmission system operators (TSOs) and government agencies there. The interim report of the research was published in May of 2017.

The main purpose of this presentation is to introduce basic contents of the interim report by the study group and help readers to understand current discussions on international grid interconnections in Japan.

\section{Basic Concept of an International Power Grid}

In Japan, little is known about international power grids. The country has no international connections in the first place, and few believe any such system will be built in the near future. However, looking at the world, we find cross-border power trade as common practice. Figure 1 shows how much electricity is traded between countries. The import and export ratios are defined as the proportion of imported and exported electricity to generation, respectively, both on an annual basis. In Europe as a whole, import and export ratios are $11.3 \%$ and $11.2 \%$, respectively, a higher level of interconnection on the globe. In the region, Denmark stands

\footnotetext{
*Corresponding author: r.omatsu@renewable-ei.org
} 
above $30 \%$ in both ratios while Belgium and Italy have high import ratio, and France and Norway have high export ratio. Despite variations between regions, electricity is tradable, and can be reasonably imported and exported with economic benefits if there is a physical interconnection, a fact that must be recognized.

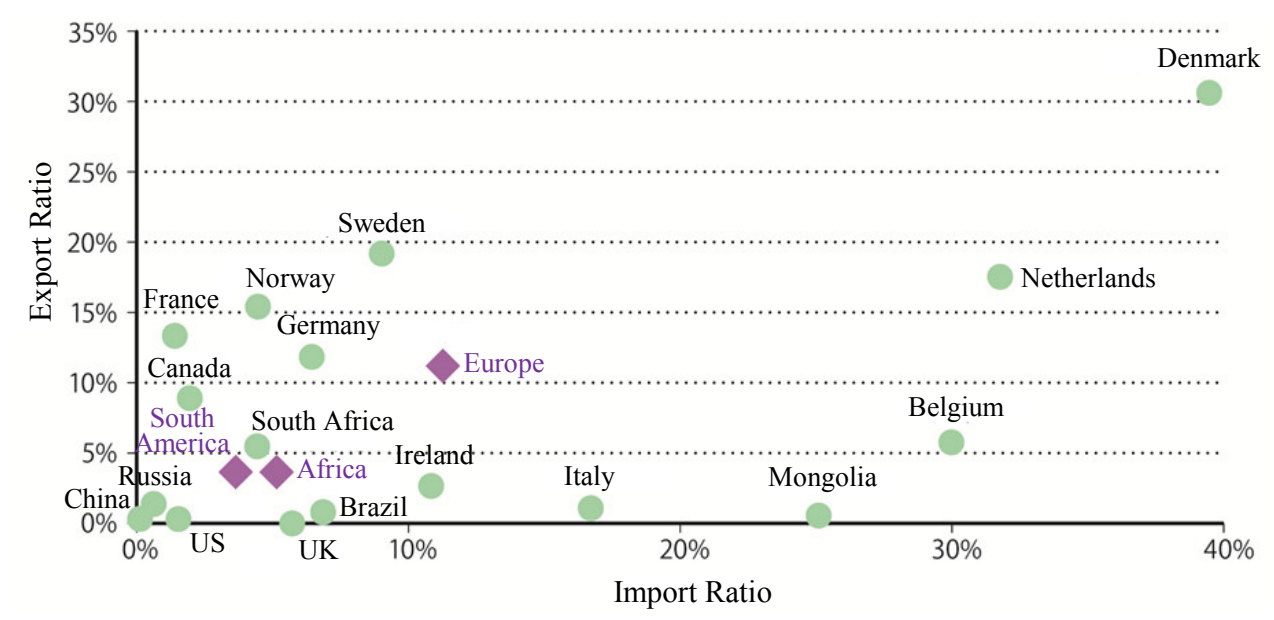

Fig. 1. Electricity import and export ratios of major countries and regions (FY 2014) Source: IEA, Electricity Information 2016.

Why, then is the international power grid needed?

First, it leads to improvements in economic efficiency through international competition with more players, lowering the cost of electricity supply. That is, a country where electricity is supplied at a higher price could import cheaper power from another and supply it at a lower price. The greater the difference in electricity prices, the greater the benefit. This is a basic function any trade would perform. Just as is the case with ordinary goods, an electricity market, when expanded in size, becomes more economically efficient. Countries with large markets could obtain greater effect from interconnections.

That may sound as if a country originally enjoying a lower electricity rate ends up with higher price increases and suffers a loss. That is not necessarily the case. First, competitive power producers can expand into overseas markets. Export of cheap power emerges as a new business. In addition, electricity prices are subject to fine variations according to time of day and other conditions aside from average prices.

Second, inter-regional or international transmission operation contributes to a stable supply of electricity. A larger network generally makes it easier to balance supply and demand by integrating large numbers of power plants and consumers. Even with an abrupt fluctuation taking place somewhere in the network, it can respond more flexibly. A network connecting countries with different power supply structures or supply-demand patterns delivers especially great complementarity. They can also share reserve capacities.

Third, the international power grid is an effective solution to output fluctuation, and helps integrate more renewables. A larger share of wind and solar power comes with greater fluctuations of supply along with changes in weather, a challenge to grid operation Interconnection is the ultimate form of inter-regional transmission operation, and generally helps secure stability of power supply, especially when much of the supply comes from variable power sources. 


\section{The Current State of the International Power Grid in Europe}

In the Interim Report Study Group closely studied experiences of power grid interconnections in European countries.

The history of the international power grid in Europe goes back 100 years. Among the Nordic countries, interconnection was constructed between Denmark and Sweden in 1915. In continental Europe, France, Switzerland, and Italy were connected together through 700$\mathrm{km}$ interconnection in 1920. Then, after World War II, European countries started constructing interconnection on a large scale for efficient use of their limited energy resources, and international trade of electricity expanded.

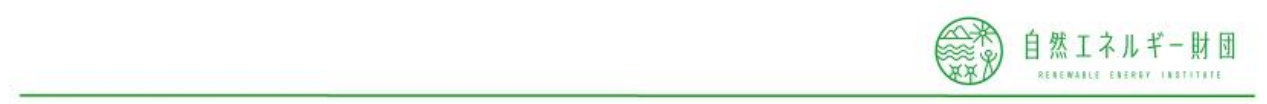

【Since 1910s】

- 1915 Denmark-Sweden Interconnection

- 1920 Interconnection between France, Switzerland and Italia.

\section{【After WW II 】}

- 1951 UCPTE among 8 countries. (West-Germany, France, Italy and others)

$\cdot 1963$

NORDEL in Northern Europe

UFIPTE by France, Spain and Portugal

\section{【Currently】}

The region is divided into four synchronous grids, Continental Europe, Nordic, UK, and Baltic, and they are connected asynchronously through direct current transmission, so that electricity trade can be conducted among them.

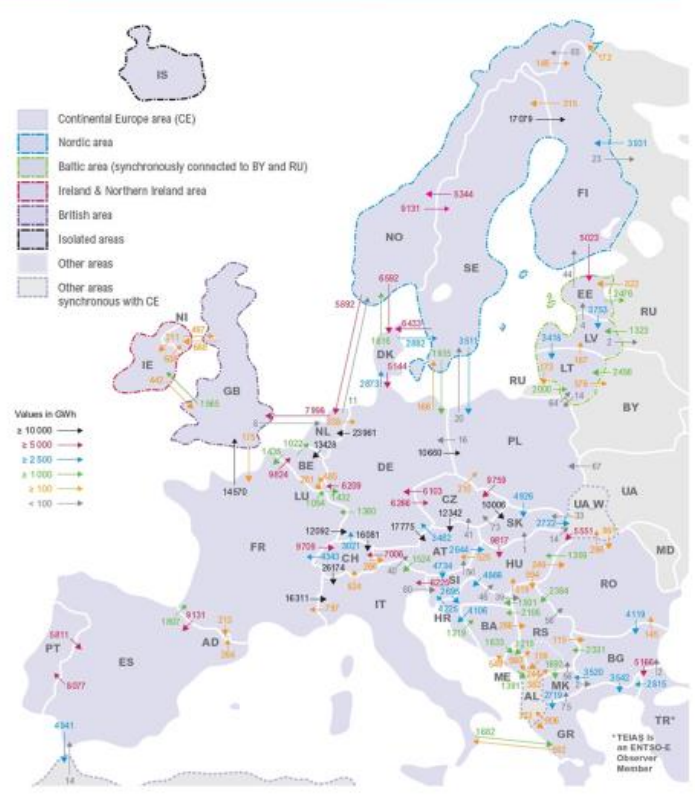

Fig. 2. Power flows between countries in Europe (2015)

Source: ENTSO-e, Statistical Factsheet 2015

Countries can expect to benefit from international power grids in different ways according to conditions they are in. Table 1 summarizes benefits the United Kingdom, Norway, Denmark, and the Netherlands each expect. Interconnection is expected to play some role when they work on challenges they face and strategic goals they set, such as high electricity price, changing power supply structure, export of electricity at lower prices, and solutions to fluctuations in renewables. Another factor that should be noted is that interconnection benefits both countries it links. For instance, Denmark and Germany, both holding a large amount of wind power capacities, can trade between them to balance supply and demand. Electricity they produce at a lower marginal cost drives down day-ahead spot prices, spreading benefits over countries around them, unless transmission lines are too congested. 
Table. 1. Major benefits expected from interconnection for countries (Case of HVDC cables)

Source: Created by Renewable Energy Institute based on available data.

\begin{tabular}{|c|c|c|c|c|c|}
\hline \multirow{2}{*}{ Country } & \multirow{2}{*}{ Challenges } & \multicolumn{4}{|c|}{ Major benefits expected by connected countries } \\
\hline & & UK & Norway & Denmark & Netherlands \\
\hline \multirow{2}{*}{$\begin{array}{c}\text { UK } \\
\text { Norway }\end{array}$} & $\begin{array}{l}\text { Higher shares of thermal and } \\
\text { nuclear power. Replacing them in } \\
\text { the future is a challenge. Higher } \\
\text { wholesale electricity prices than in } \\
\text { Nordic countries and the Continent. }\end{array}$ & - & $\begin{array}{l}\text { Cheaper } \\
\text { hydropower. } \\
\text { NSL }\end{array}$ & $\begin{array}{l}\text { Cheaper } \\
\text { excess wind } \\
\text { power. } \\
\text { Viking Link }\end{array}$ & $\begin{array}{c}\text { Cheaper power. } \\
\text { BritNed }\end{array}$ \\
\hline & $\begin{array}{l}98 \% \text { of electricity comes from } \\
\text { hydropower. Hydropower is } \\
\text { cheaper while securing capacities } \\
\text { in drought is a challenge. }\end{array}$ & $\begin{array}{l}\text { Supply } \\
\text { capacities in } \\
\text { drought. } \\
\text { NSL }\end{array}$ & - & $\begin{array}{c}\text { Supply } \\
\text { capacities in } \\
\text { drought. } \\
\text { Cheaper } \\
\text { excess wind } \\
\text { power. } \\
\text { Skagerrak }\end{array}$ & $\begin{array}{c}\text { Supply } \\
\text { capacities in } \\
\text { drought. } \\
\text { Supply of gas- } \\
\text { fueled power at } \\
\text { times when } \\
\text { cheaper. } \\
\text { NorNed }\end{array}$ \\
\hline Denmark & $\begin{array}{l}\text { Its wind power plants have a } \\
\text { maximum capacity larger than } \\
\text { demand at specific times. } \\
\text { Optimizing wind power use is a } \\
\text { challenge. }\end{array}$ & $\begin{array}{l}\text { Higher } \\
\text { adjustability. } \\
\text { Viking Link }\end{array}$ & $\begin{array}{l}\text { Cheaper } \\
\text { hydropower. } \\
\text { Higher } \\
\text { adjustability. } \\
\text { Skagerrak }\end{array}$ & - & $\begin{array}{l}\text { Higher } \\
\text { adjustability. } \\
\text { COBRAcable }\end{array}$ \\
\hline Netherlands & $\begin{array}{l}\text { Electricity is supplied mainly by } \\
\text { gas and coal-fired power plants. } \\
\text { Higher wholesale electricity prices } \\
\text { than in neighbors (Germany and } \\
\text { France). }\end{array}$ & $\begin{array}{l}\text { Enhanced } \\
\text { supply } \\
\text { capacities. } \\
\text { BritNed }\end{array}$ & $\begin{array}{l}\text { Cheaper } \\
\text { hydropower. } \\
\text { NorNed }\end{array}$ & $\begin{array}{c}\text { Cheaper } \\
\text { excess wind } \\
\text { power. } \\
\text { COBRAcable }\end{array}$ & - \\
\hline
\end{tabular}

\section{The Current State and Feasibility of an International Power Grid in Northeast Asia}

\subsection{Basic conditions for future grid interconnections in NEA}

From the viewpoint of development of interconnection, the greatest distinguishing feature of Northeast Asia is the fact that multiple large-scale demand zones, centers of economic activity, adjoin each other. Seen in terms of the size of economy (Table 1), Northeast Asia stretches across China, Japan, and South Korea, fairly large economies (the 2nd, 3rd, and 11 th largest, respectively, in dollar-denominated nominal GDP in 2015) lying side by side. The four countries of Japan, China, South Korea, and Mongolia together account for $76 \%$ of Asia's power generation and $77 \%$ of its power consumption.

Current conditions that interconnection and electricity trading see as a given differ between countries depending on systems and institutions they have adopted, such as whether transmission companies, which operate interconnections, are separated from generation business (state of unbundling), and whether any wholesale electricity trading market is in place and works to set electricity prices.

First, each of these countries permits private-sector participation in their markets, including foreign investments, in its power-generating sector. Second, in each of these countries other than Japan, unbundling is introduced, with the grid operated by a state-run transmission company. Japan is in the process of a legal unbundling planned for completion by 2020 . Third, while no international market for transactions in wholesale electricity yet exists in Northeast Asia similar to Nord Pool, Japan, South Korea, and Russia each have their own wholesale electricity trading markets as part of initiatives they are pursuing for market liberalization. 
While still lagging behind Europe in electricity market liberalization, as shown above, all the countries in the region but Japan have already set up independent transmission companies, and these transmitting companies also are demonstrating proactive approaches to interconnection. In part because those companies are owned and run by state, some arrangements could be made between different regulations and systems once any agreement is formed among national governments.

Table. 2. The Current State and Feasibility of an International Power Grid in Northeast Asia.

Source: Created by Renewable Energy Institute based on data released by national governments and international organizations.

\begin{tabular}{|l|rr|c|c|c|} 
& $\begin{array}{c}\text { GDP (in billion dollars) } \\
\text { Figures in parentheses are GDP } \\
\text { per capita (in thousand dollars) }\end{array}$ & $\begin{array}{c}\text { Population } \\
\text { (in million people) }\end{array}$ & $\begin{array}{c}\text { Electricity } \\
\text { generated } \\
\text { (in TWh) }\end{array}$ & $\begin{array}{c}\mathrm{CO}_{2} \text { emissions } \\
\text { (in million tons } \\
\mathrm{CO}_{2} \text { ) }\end{array}$ \\
\hline China & 8,909 & $(6.5)$ & 1,376 & 5,811 & 9,154 \\
\hline Japan & 5,986 & $(47.2)$ & 127 & 1,036 & 1,208 \\
\hline South Korea & 1,267 & $(25.0)$ & 50 & 522 & 649 \\
\hline Mongolia & 12 & $(3.9)$ & 143 & 1,063 & 18 \\
\hline Russia & 1,616 & $(11.0)$ & 1,699 & 8,437 & 12,512 \\
\hline Northeast Asia & 17,790 & $(\sim 10.5)$ & 7,349 & 24,098 & 33,508 \\
\hline World & 74,889 & $(10.2)$ & $20-25 \%$ & $30-35 \%$ & $\sim 37 \%$ \\
\hline Share of Northeast Asia & \multicolumn{2}{|c|}{$20-25 \%$} & United Nations & $\begin{array}{l}\text { BP; For Mongolia, } \\
\text { figure from IEA in 2014 }\end{array}$ & $\begin{array}{l}\text { BP; For Mongolia, } \\
\text { figure from IEA in 2014 }\end{array}$ \\
\hline Source & $\begin{array}{l}\text { World Bank } \\
\text { *Constant 2010 }\end{array}$ & & & \\
\hline
\end{tabular}

There are large differences between countries in price level and power demand patterns, which creates good conditions for mulual comprementarities achievable through grid interconnection.

\subsection{Rapid expansion of Renewable Energy as a driver for interconnections.}

In North East Asia each country has been actively promoting investments in domestic renewable energy. Against the backdrop of serious air pollution issues and remarkable decrease in the costs of renewable energy installation and operation, this movement is expected to be further accelerated.

According to future forecasts announced by international agencies for 2030-2050, in 2030 it is projected that $30-50 \%$ of electricity generated in each country of Northeast Asia will be supplied from renewable energy (Figure 3). In terms of the period up to 2050, there is a report (NDRC) forecasting that renewable energy will account for $80 \%$ of power generation in China.

In considering a potential for power supply by renewable energy in Northeast Asia, Mongolia is particularly an important country. The potential for wind power and solar PV mainly in the area around the Gobi Desert in the south has been highly valued.

IRENA's "Mongolia Renewables Readiness ASSESSMENT" (March 2016) estimates RE potential in Mongolia as 10,673 TWh for wind power and 4,777 TWh for solar PV. The total potential power generation will be $15,000 \mathrm{TWh}$ or more, which is much more than the total electricity demand in China (5,693 TWh) and Japan (949 TWh) in 2015. It is expected that Mongolia will supply power to neighboring countries in the future by utilizing its rich renewable energy.

As above mentioned, Northeast Asia is a region with not only major economies adjacent to each other but also a high potential for power generation by renewable energy. In order to 
make the most of renewable energy that has been developing in Asian countries, grid flexibility for power interchange across Asia is required, and the need of an international power grid is increasing.

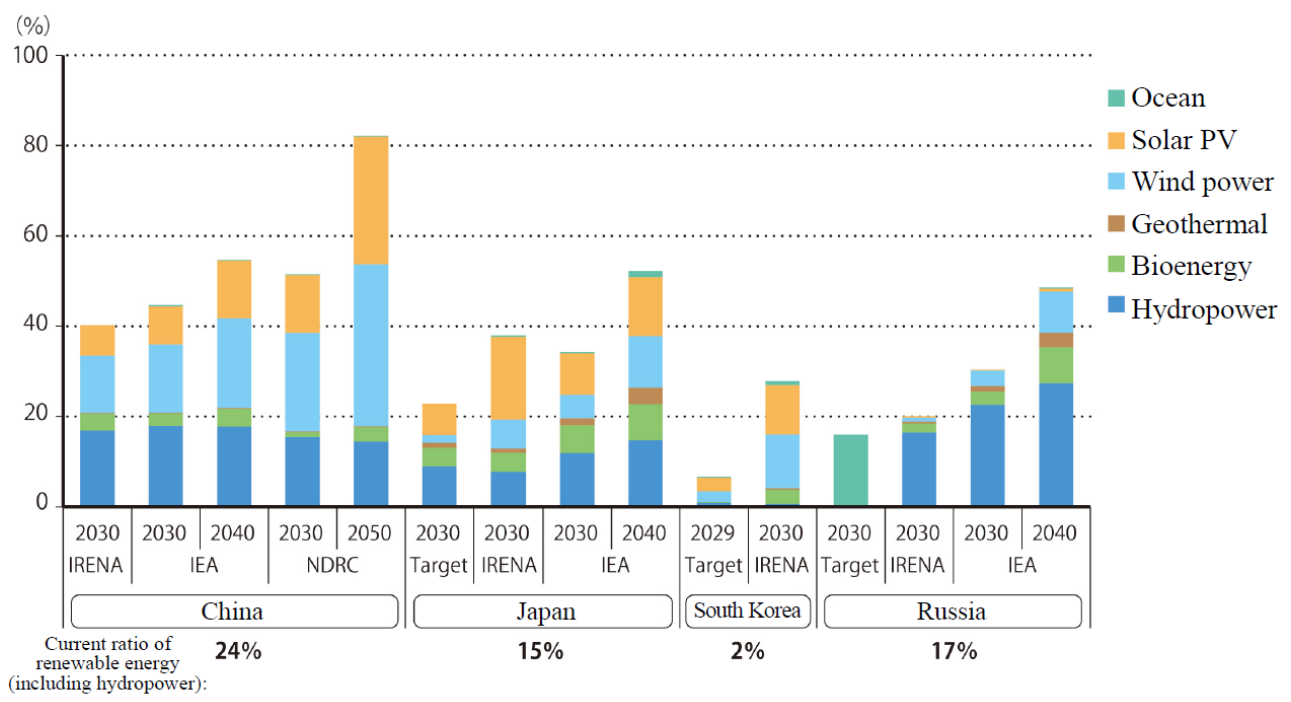

Fig.3. Future prospects of power supply structures in Northeast Asia (2030-2050)

Source: Created by Renewable Energy Institute based on IRENA (REmap 2016), IEA (WEO 2016 450 scenario), NDRC (China RE Outlook 2016 - High Penetration scenario)

\subsection{International power grid schemes surrounding Japan: From concept to the real plan}

For last decades, different research institutes and organizations have proposed it's own concepts for Power grid interconnection in North East Asia.

Since 2011, international power grid concept has been proposed mainly by power and transmission companies in Northeast Asia. Inspired in part by the Asia Super Grid vision (promoted by Renewable Energy Institute), major transmission companies in Asia start to formulate their own international power network scheme in Asia in conjunction with the vision.

For example, the Korea Electric Power Corporation announced the Northeast Asia Super Grid plan in 2014 in cooperation with the Russian research institution Skoltech and other organizations. The company set out the concept of a Smart Energy Belt that connects Japan, China, South Korea, Russia, and Mongolia with a highly efficient electricity supply-demand system combining power storage technologies and smart grid

In 2015, the State Grid Corporation of China (SGCC), the world's largest power transmission company, announced its Global Energy Interconnection (GEI) vision. In March 2016, the international nonprofit foundation Global Energy Interconnection Development and Cooperation Organization (GEIDCO) was established with the goal of realizing this GEI concept. Consisting of research institutions and relevant enterprises in various countries, GEIDCO aims to develop a global power grid to utilize renewable energy.

It also is worth noting for Japan that the Russian government has formally made a specific proposal on interconnections between the two countries. In September 2016, the Eastern Economic Forum was held in Vladivostok in the Far East. At its plenary session, President Putin said, "we support the initiative of Russian, Japanese, South Korean, and Chinese 
companies to create an Energy Super Ring linking our countries." He also proposed setting up an intergovernmental working group for the initiative.

In this way, enterprise-driven movements towards the realization of the Asia international power grid scheme have been accelerated since 2016 .

\section{Legal considerations to work on international transmission in Japan}

Since the legal structure on electricity business in Japan did not envision interconnection, there is a high likelihood for necessity of consideration on legal and regulatory reforms. Although a wide variety of matters need to be examined, we will clarify the issues focusing on the license for interconnection business, and regulations on installation of undersea transmission lines and electricity market trading.

The first topic is the license for interconnection business. When considering international power grid connection as having the same characteristics as regional grid connections, it is conceivable that the Transmission Business license under current law (Article 27-4 of the Electricity Business Act, EBA) could be used. As the current law does not specify provisions on connection to overseas, these provisions can be added. The Telecommunications Business Act (TBA) can be used as a reference. This law calls for licensing of telecommunication enterprises regardless of whether they are international or domestic (Article 9 of TBAe). Its provision specifies that a telecommunications enterprise shall obtain authorization from the Minister of Internal Affairs and Communications when it intends to conclude an agreement on important matters related to telecommunications operation with foreign governments or foreign companies (Article 40 of TBA, Article 27 of the Ordinance for Enforcement of TBA).

Another method is to establish new licenses especially for interconnections. For example, we can add a new section titled "International transmission business" to specify the details of the license.

Among other countries, there are examples of both those that specify explicitly the differences between international transmission licenses and standard transmission licenses under the law (England and Wales, Ireland, etc.), and those that do not (Northern Ireland, France, United States, Canada, etc.). In the latter case, some specify the operation of international transmission business as a special case in the details of the individual license, and some require authorization from the government for installation of interconnections and international electricity trading. Various forms of regulations can be considered, depending on the existing systems or policies of the country.

Second, as for regulations on installation of undersea transmission lines, EBA has no specific provisions concerning installation of undersea transmission lines. Each country may install undersea cables freely in extraterritorial waters (refer to Articles 57, 79, and 87 of the United Nations Convention on the Law of the Sea). Since the waters between Japan and Russia and South Korea, anticipated as partners for installation of such cables, consist only of each country's exclusive economic zone, once agreements are concluded with these countries, there would be no particular problems with their installation under the treaty. Also, many fiber-optic cables for telecommunication are installed in the seas around Japan (Figure 4).

And in fact, multiple undersea power cables have been installed in the seas of Japan. Therefore, nonexistence of the provisions would not be impediments to the installation. However, the Fishery Act does have provisions concerning installation of underwater cables (Article 39(1)). As a reference, TBA has provisions on coordination with fishing rights and protection of submarine cables (Articles 140 through 143). Also, the Wire Telecommunications Act prohibits the installation of unauthorized international 
communications cables (Article 4). Therefore, it is worth considering that EBA would include similar provisions.

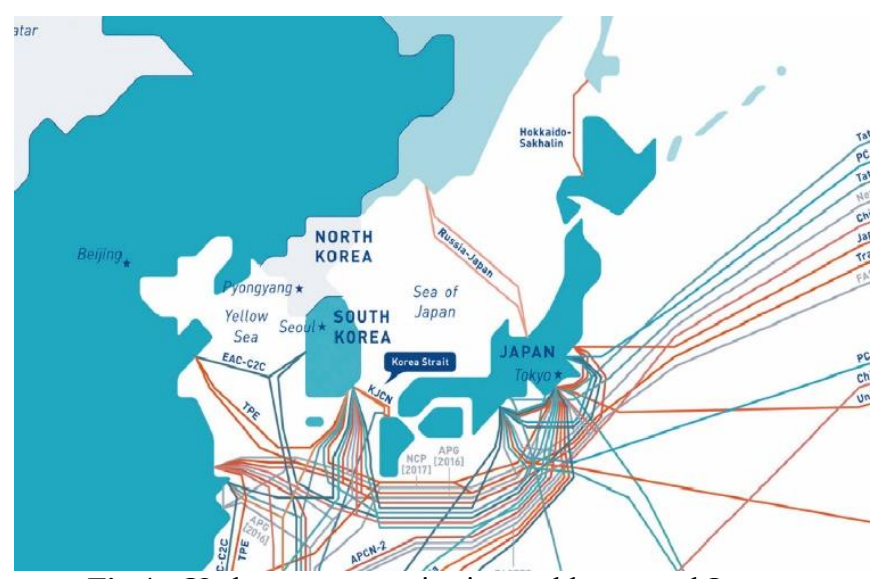

Fig.4. Undersea communications cables around Japan

source : TeleGeography Submarine Cable Map 2016.

Third, it is necessary to ensure participation in electricity markets from overseas. Now we would like to examine whether the Japan Electric Power Exchange (JEPX) needs some amendments to current market rules to allow international trading of electricity. If Japan imports electricity from overseas, foreign power generation companies or power trading companies may participate in the market as sellers. If Japan exports electricity to overseas, foreign retailers or power trading companies may participate in the market as buyers.

\section{Conclusion}

As we have discussed so far, an international power grid is economically reasonable in general. Also, compared with domestic grids, there is no particular technical difficulty in an international power grid. These aspects have been proved by the long history of the international power grid in Europe. Moreover, interconnections are utilized not only in Europe but also in Southeast and South Asia. In light of global renewable energy expansion in the future, many interconnection construction projects are planned across the world. We can say that there are no absolute reasons that it would be impossible to construct or operate international power grids in Northeast Asia including Japan.

Actually, there may have been little need for an international power grid in Japan or Northeast Asia in the past. However, now that China has the largest installed capacity of renewable energy in the world and Russia and Mongolia have huge potential, we should change the recognition of the continuing situation where Japan remains unconnected with any neighboring countries. We believe that the 21 st century should be the age of electricity trading not only in Northeast Asia or all over Asia, but also on a global basis. The fact that other countries of Northeast Asia, as well as their transmission and power companies, have made proposals for international power grids connecting this region should be given serious consideration.

The time has come for us to break through the preconceived notion that as an island nation an international power grid would be impractical in Japan and to recognize that such a network is essential for both the Japan of today and other countries in Asia and could, ultimately, contribute to resolving global energy issues. 
At the same time, the most important challenge for Japan to launch a specific international power grid project is the determination as a nation. In order to bring the project into practice, the government must have a firm commitment to the realization of international transmission of electricity and begin formal discussions with other countries' governments.

\section{Reference}

1. Asia International Grid Connection Study Group, Interim Report (2017) 